Disponível em

http://www.anpad.org.br/rac

RAC, Rio de Janeiro, v. 19, Edição Especial, art. 1, pp. 1-19, Maio 2015

http://dx.doi.org/10.1590/1982-7849rac20151452

$($ (c) EY-NO

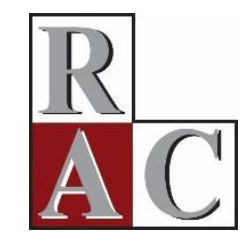

\title{
Internationalization and Corporate Cash Holdings: Evidence from Brazil and Mexico
}

Newton Arata

Fundação Getulio Vargas - FGV/EESP

Hsia Hua Sheng

Fundação Getulio Vargas - FGV/EESP; Universidade Federal de São Paulo - UNIFESP/EPPEN

Mayra Ivanoff Lora Fundação Getulio Vargas - FGV/EESP

Artigo recebido em 17.05.2013. Última versão recebida em 13.08.2014. Aprovado em 15.08.2014. 


\title{
Resumo
}

Estendemos estudos anteriores a respeito do nível de caixa e seus determinantes de modo a analisar a relação entre o grau de internacionalização e o nível de caixa das empresas. Diferente das empresas domésticas, as empresas internacionalizadas possuem mais oportunidades de investimento e enfrentam mais adversidades em seus negócios. Utilizamos, para tanto, uma amostra de empresas de capital aberto não financeiras do Brasil e do México para o período de 2006 a 2010. Regressões em painel com efeitos fixos foram aplicadas. Nossos resultados sugerem que o grau de internacionalização é um determinante de caixa e que o nível de caixa aumenta de forma quadrática à medida que o grau de internacionalização da empresa aumenta. Esse comportamento é diferente daquele de empresas norte-americanas, estudadas por Chiang e Wang (2011). Assim como a estudos anteriores, tanto previsões de Trade-Off quanto Pecking Order são relevantes como variáveis de controle em nosso modelo. Por fim, observou-se que, no período antecedente à crise, as empresas seguraram menos caixa em seus balanços.

Palavras-chave: gestão de caixa; grau de internacionalização; empresas multinacionais.

\begin{abstract}
This research expands on previous studies of cash holdings and their determinants by studying the relationship between the degree of internationalization and the level of corporate cash holdings. We used a sample of nonfinancial, publicly traded companies from Brazil and Mexico for the period from 2006 to 2010. Our results suggest that the degree of internationalization is a determinant of cash, and that cash holding increases quadratically as the degree of company internationalization grows. Such behavior was different from the North American company studies in Chiang and Wang (2011). Similar to previous studies, both Trade-off and Pecking Order predictions are relevant control variables in our model. Finally, companies held less cash on their balance sheets during the precrisis period.
\end{abstract}

Key words: cash management; degree of internationalization; multinational companies. 


\section{Introduction}

During international expansion, companies may face a number of concerns, such as differences in currency, language, culture, politics and economics. Additionally, companies also worry about their own financial factors: capital structure, amount of invested assets, cash holding, and price of products/services, among others. Such a scenario leads to the following question: would internationalization influence these factors differently depending on whether companies operate internationally or domestically?

Some studies point to differences between multinational companies (MNCs) and domestic companies (DCs). On capital structure, Desai, Foley and Hines (2004) found evidence that MNC subsidiaries in countries with underdeveloped capital markets or weak creditor rights have higher interest rates on loans than DCs. Lu and Beamish (2004) found that the performance ratio between MNCs and the level of internationalization follows a horizontal S-curve. The return obtained from a diversification strategy was related to costs and benefits, which varied according to company internationalization.

In other words, internationalization has a different impact on the financial factors of companies with international operations and domestic companies. More specifically, the degree of internationalization may lead to different behaviors for company's cash holdings.

Presently, there are few studies linking internationalization and cash holding. The vast majority of those articles have the determinants of corporate cash holdings as their starting point. Opler, Pinkowitz, Stulz and Williamson (1999) are among the main references on the subject.

Over the past few years, studies that approach cash holding in terms of internationalization have become more popular. Based on the principles of corporate governance, Chang and Noorbakhsh (2006) found that foreign direct investments act as cash substitutes, while Foley, Hartzell, Titman and Twite (2007) used a tax-based explanation to analyze cash holding behaviors. Differently from previous studies, Chiang and Wang (2011) studied the direct relationship between a firm's international expansion and cash holding. They found evidence that multinational companies hold more cash than domestic firms do and this relationship can be depicted as an inverted-U-shape, but this was limited to lower levels of internationalization.

In the context of internationalization, this article analyzes whether the degree of internationalization is a determinant of cash for companies in Latin America, particularly in Brazil and Mexico. Based on the Trade-Off and Financial Hierarchy theories prediction, we defined control variables based on firm characteristics as determinant of cash holdings.

We hypothesize that the expansion of internationalization is one of the determinants of corporate cash holding. Following Chiang and Wang (2011), we also hypothesize an inverse-U-shape relationship between cash holdings and internationalization. This work contributes to the financial cash policy discussion regarding Latin American firms.

Brazil and Mexico have been selected for two reasons. First, their importance in Latin America: according to UN statistics, in 2010 these two countries accounted together for $63.2 \%$ of Latin America's GDP and $74.1 \%$ of the market value of publicly traded companies listed in the region; second, the different financing constraints faced by firms. Strong economic integration with the United States makes Mexican companies turn to North American capital markets for financing (Canuto \& Santos, 2003). In addition, unlike Brazilian firms, Mexican firms use more cash reserves instead of trade credit during financial crises (Sheng, Bortoluzzo, \& Santos, 2013).

Our results suggest that the degree of internationalization is a determinant of cash, and that cash holding increases quadratically as the degree of company internationalization grows. Companies with a higher degree of internationalization show different cash level behaviors than domestic companies. 
Thus, companies should consider the degree of internationalization when they do their treasury and financial planning.

\section{Theoretical Foundation}

\section{Determinants of cash holding}

According to the literature, some explanations for companies to hold their assets are: transactional (Baumol, 1952; Miller \& Or, 1966), precautionary (Acharya, Almeida, \& Campello, 2007; Bates, Kahle, \& Stulz, 2009; M. A. Ferreira \& Vilela, 2004; Opler, Pinkowitz, Stulz, \& Williamson, 1999), tax (Foley, Hartzell, Titman, \& Twite, 2007) and agency conflicts (Chang \& Noorbakhsh, 2006; Dittmar \& MahrtSmith, 2007; Dittmar \& Mahrt-Smith, \& Servaes, 2003; Harford, Mansi, \& Maxwell, 2008; Jensen, 1986). This list could also include cash reserves for the acquisition of other companies and for regulatory purposes.

Among these reasons, two main financial theoretical models help identify which firm characteristics influence cash-holding decisions. This discussion follows Opler et al. (1999), and analyzes this issue using the Trade-Off and Pecking Order theories.

\section{Trade-off theory}

The Trade-Off theory argues that management should set optimal levels of cash holdings by weighing the marginal cost and marginal benefits of holding cash to maximize shareholder wealth. According to Keynes (1936/2009), there are two main benefits from holding liquid assets. The first benefit comes from the transaction factor: companies save transaction costs to raise funds and do not have to liquidate key assets to make payments. The second benefit comes from the precautionary factor: in that case, companies can use liquid assets to finance their short and long-term investments if other sources of funding are excessively costly.

However, managers and shareholders look at costs and benefits differently. Managers have great incentive to hold cash due to managerial discretion and firm risk reduction. Such discretion plays an important role in explaining cash holding (Dittmar et al., 2003). A greater preference for liquid assets can lead managers to overestimate the importance of the precautionary motive for holding cash (Opler et al., 1999).

According to Opler et al. (1999) and Bates, Kahle and Stulz (2009), cash holdings are negatively related to company size, net assets, payment of dividends and debt, and positively related to growth opportunities and cash flow variability. For Bates et al. (2009), cash holdings are also negatively related to capital expenditures. For Chang and Noorbakhsh (2009), cash holdings are positively related to cash flow.

Additionally, based on corporate demand of liquidity arguments (Almeida, Campello, \& Weisbach, 2002), M. A. Ferreira and Vilela (2004) argue that cash holding allows the pursuance of investment projects with positive net present value (NPV) even when financial constraints are met.

\section{Financial hierarchy theory}

Myers' Pecking Order theory (1984) suggests that there is no optimal level of debt. Under normal circumstances, firms finance their investments first with retained earnings, then with low-cost debt, and finally with equity. That financing hierarchy helps firms to reduce asymmetric information cost and other financing costs. According to Dittmar, Mahrt-Smith and Servaes (2003), cash balances are simply the outcome of the investment and financing decisions made by the firm as suggested by the Pecking 
Order of financing. In other words, as long as there is no optimal level of debt, there might not be an optimal amount of cash (Opler et al., 1999).

According to the Pecking order theory, the relationship between debt leverage and cash holding is negative (M. A. Ferreira \& Vilela, 2004). Debt typically grows when investments exceed retained earnings and falls when investments are lower than retained earnings. As firms with low cash flow draw down their cash and issue debt to finance investment, cash holdings follow an inverse pattern of debt evolution.

\section{Internationalization expansion and cash holding}

Some studies in the literature point to differences between multinational companies (MNCs) and domestic companies (DCs). On capital structure, Desai et al. (2004) found evidence that MNC subsidiaries in countries with underdeveloped capital markets or weak creditor rights present higher interest rates on loans than DCs, and that loans from their parent companies replace three quarters of these companies' needs for foreign capital.

Using a sample database of 1,489 Japanese firm-year observations over twelve years, Lu and Beamish (2004) found that the relationship between MNC performance and internationalization level followed a horizontal S-curve. The return obtained from diversification strategies was related to costs and benefits, which varied according to company internationalization.

Reeb, Kwok and Baek (1998) analyzed data on 3,903 U.S. companies between 1987 and 1996 and found a positive relationship between internationalization levels and the risk faced by MNCs due to the increased variability of cash flows caused by currency exchange and political risks, information asymmetry and agency problems.

However, few researchers have established a direct relationship between International Expansion and Cash Holdings. Chang and Noorbakhsh (2006) studied the influence of foreign direct investments (FDI) upon company cash holding. Using the World Scope 2010 database, a sample of 48 countries and 20,987 companies, they introduced a new control variable - FDI - and found evidence that the entry of FDI acts as a cash substitute for companies in the seven largest economies, but it is a complement for companies in other countries.

Chiang and Wang (2011) also found evidence that U.S. multinational firms hold more cash than domestic firms do, and that the degree of internationalization is a determinant of cash. Furthermore, they compared the behavior of cash holdings with the degree of internationalization and found an inverse-Ushaped relationship; i.e. the cash level increases as international expansion takes place, but this applies solely to lower levels of internationalization.

In Brazil, the discussion of cash determinants has not yet addressed the influence of internationalization in companies' cash holdings. Carracedo (2010) and Koshio (2005) analyzed cash determinants for Brazilian companies according to the Static Trade-Off, Pecking Order and Agency theories, and found that none of them was able to explain company cash determinants. Nevertheless, these theories may be considered complementary rather than divergent.

Using the financial constraint framework, Zani and Procianoy (2005) pointed out that cash holding was a crucial strategy for Brazilian firms - even financially unconstrained ones. The evidence suggests that asymmetric information problems still affect Brazilian financial markets. Pereira (2011) and Benegas (2008) studied the influence financial constraints have on company cash levels. The results showed that companies hold more cash in their assets during crisis periods, when information asymmetry is higher. Dylewski (2010) identified a growing trend over the last few years where Latin American companies have hoarded net assets. Recently, Kirch, Procianoy and Terra (2014) confirmed that Brazilian firms choose different investment strategies according to their ability to obtain external financing. While financially constrained firms follow Almeida and Campello's (2007) model predictions, financially unconstrained firms behave in accordance with the neoclassic model. 
E. J. Ferreira and Leal (2010) studied cash holdings in Brazilian and American companies and found evidence that companies which retained large cash holdings were associated with increased growth opportunities, and were therefore in line with the maximization of shareholder value, as well as management qualification and company profitability.

Freitas (2006) studied the influence of internal resource generation on Brazilian companies as a determinant factor for the companies' investment in fixed assets. The study found that, depending on company characteristics, internal generation of resources is relevant to investment. Size, leverage and percentage of common shares held by the controlling shareholder(s) affect the sensitivity of the investment to the generation of internal funds.

\section{Description of cash determinants variables}

We hypothesize that internationalization expansion is one of the determinants of corporate cash holding. Following Chiang and Wang (2011), we also hypothesize an inverse-U-shaped relationship between cash holdings and internationalization. The degree of company internationalization (DOI) represents their international expansion.

According to Johanson and Vahlne (1977), export activity is typically the first stage of a company's internationalization process, possibly a step for becoming a multinational company. We define the degree of internationalization (DOI) as percentage of export sales (Doukas \& Pantzalis, 2003).

Sullivan (1994) suggests the use of a combination of several factors as a proxy for the DOI, including the ratio between foreign sales and total sales, the ratio between foreign assets and total assets, the ratio between foreign subsidiaries and total subsidiaries, the geographical dispersion of international operations and the international experience of the company's top management. Doukas and Pantzalis (2003) have provided a simpler definition for DOI: the ratio between foreign sales and total sales and the ratio between foreign assets and total assets. Because there is limited information for Brazil and Mexico, we followed Doukas and Pantzalis' (2003) methodology and adopted only the ratio between foreign sales and total sales as a proxy for the degree of company internationalization.

Following Bates et al. (2009) and Ozkan and Ozkan (2004), we define cash ratio (cashr) as cash and short-term investments divided by total assets, because companies that have large amounts of cash and short-term investments cause an outlier problem when we consider the ratio between cash and liquid assets. The use of the logarithm for the ratio between cash and liquid assets (Foley et al., 2007) diminishes the magnitude of the outliers, but does not remove the problem completely. We also found other proxies for cash level in the literature:

1. Cash/assets ratio $=$ cash and short-term investments divided by total assets. (Bates et al., 2009; Ozkan $\&$ Ozkan, 2004).

2. Cash/net assets ratio $=$ cash and short-term investments divided by total net cash assets and shortterm investments. (Opler et al., 1999).

3. Logarithmic cash/net asset ratio $=$ logarithm of cash and short-term investments divided by total net cash assets and short-term investments. (Chang \& Noorbakhsh, 2009; Faleye, 2004; Foley et al., 2007).

Supported by the theory discussions in the previous section, the following firm's characteristics were defined as our control variables.

Company size (size). Economies of scale favor larger companies, which hold less cash (Bates et al., 2009; Mulligan, 1997). Moreover, large companies tend to be more diversified (Titman \& Wessels, 1988 ) and present less asymmetric information when compared to smaller companies. Thus, a negative relationship between cash level and company size is expected. Following Chang and Noorbakhsh (2009) and Foley et al. (2007), the logarithm of total assets was used as a proxy for company size. 
Leverage (lev). If the debt is high enough, companies will use cash to reduce leverage, resulting in a negative relationship between leverage and cash level (Bates et al., 2009). On the other hand, less leveraged companies are less subject to external monitoring, which allows management to hold more cash (M. A. Ferreira \& Vilela, 2004). Acharya, Almeida and Campello (2007) demonstrated that holding cash allows companies with limited access to capital markets to protect themselves against future uncertainty, but debt reduction is the most efficient way of raising future cash flows. Therefore, companies with limited access to capital markets prefer to hold more cash rather than reduce their debts if the need to protect themselves is high, but they prefer to reduce cash when there is less need for protection.

Following Bates et al. (2009), Chang and Noorbakhsh (2009), Ozkan and Ozkan (2004) and Opler et al. (1999), we define leverage as total debt divided by total assets.

Growth opportunity (gop). Companies with greater growth opportunities hold more cash (Opler et al., 1999) and value it more than others, as financial constraints are more costly for these companies (Bates et al., 2009). Thus, it is expected that the level of cash will vary positively with respect to a company's growth opportunity. Following Bates et al. (2009), Chang and Noorbakhsh (2009), Ozkan and Ozkan (2004) and Opler et al. (1999), we used the ratio between market value and book value (total assets minus net equity, plus company market value, divided by total assets) as a proxy for growth opportunity.

Dividend dummy (div). Dividend-paying companies tend to take fewer risks and have greater access to capital markets (Bates et al., 2009). Companies that pay dividends can afford to hold less cash insofar as they are better able to raise funds when necessary by cutting dividends (M. A. Ferreira \& Vilela, 2004). Following Bates et al. (2009), Ozkan and Ozkan (2004) and Opler et al. (1999), we define the dividend dummy as 1 if the company pays dividends and 0 if not.

Net working capital to assets (nwcap). The existence of other net assets can replace company cash (Ozkan \& Ozkan, 2004) as long as they can be readily converted to cash. Net working capital comprises assets that substitute cash (Bates et al., 2009). Hence, we expect a negative relationship between net working capital to assets and cash holding. We define company net working capital to assets as current assets minus cash and short-term investments, divided by total assets, following Bates et al. (2009) and Ozkan and Ozkan (2004).

Cash flow over total assets (cf). Companies with higher cash flows accumulate more cash (Bates et al., 2009). Thus, it is expected that the level of cash will vary positively with a company's cash flow. Following Bates et al. (2009) and Opler et al. (1999), we define cash flow as earnings after interest, tax and dividends, but before depreciation.

Variability of cash flow (cfsd). Opler et al. (1999) and Bates et al. (2009) found an association between increased cash flow volatility and increased levels of cash retained by companies. The methodology for calculation followed Bates et al. (2009): first, the standard deviations were calculated for cash flow, then divided by total assets for the past 10 years and finally the average for this standard deviation was calculated for the company and its sector.

Capital expenditures (cpxa). If there is an investment in assets that can be used as collateral, it may increase the company's ability to go into debt and therefore reduce the demand for cash (Bates et al., 2009). At the same time, the investment could be a proxy for financial restrictions on growth opportunity (Bates et al., 2009). Therefore, we expect a positive or negative variation in the level of cash with the ratio between investment and total assets. Following Bates et al. (2009) and Foley et al. (2007), we define capital investment as capex divided by total assets.

Finally, we summarized all the theory discussion with their main variables in Table 1. 
Table 1

Summary of Model Predictions and Variables Definitions

\begin{tabular}{|c|c|c|c|c|}
\hline Variable & $\begin{array}{l}\text { Trade-Off } \\
\text { Theory }\end{array}$ & $\begin{array}{l}\text { Financial } \\
\text { Hierarchy Theory }\end{array}$ & Definition & References \\
\hline Cash ratio (cashr) & & & $\begin{array}{l}\text { Cash and short-term } \\
\text { investments divided by } \\
\text { total assets }\end{array}$ & $\begin{array}{l}\text { Bates et al. (2009), Ozkan } \\
\text { and Ozkan (2004) }\end{array}$ \\
\hline $\begin{array}{l}\text { Degree of } \\
\text { internationalization } \\
\text { (doi) }\end{array}$ & & & $\begin{array}{l}\text { Ratio of foreign sales over } \\
\text { total sales }\end{array}$ & $\begin{array}{l}\text { Chiang and Wang (2011), } \\
\text { Doukas and Pantzalis } \\
(2003)\end{array}$ \\
\hline $\begin{array}{l}\text { Company size } \\
(\text { size })\end{array}$ & Negative & Positive & Ln (total assets) & $\begin{array}{l}\text { Chiang and Wang (2011), } \\
\text { Chang and Noorbakhsh } \\
\text { (2009), M. A. Ferreira and } \\
\text { Vilela (2004), Foley et al. } \\
\text { (2007) }\end{array}$ \\
\hline Leverage (lev) & & Negative & $\begin{array}{l}\text { Total debt divided by total } \\
\text { assets }\end{array}$ & $\begin{array}{l}\text { Chiang and Wang (2011), } \\
\text { Bates et al. (2009), Chang } \\
\text { and Noorbakhsh (2009), } \\
\text { Ozkan and Ozkan (2004), } \\
\text { Opler et al. (1999) }\end{array}$ \\
\hline $\begin{array}{l}\text { Growth } \\
\text { opportunity (gop) }\end{array}$ & Positive & Positive & $\begin{array}{l}\text { Ratio between market } \\
\text { value and book value } \\
\text { (total assets minus net } \\
\text { equity, plus company } \\
\text { market value, divided by } \\
\text { total assets) }\end{array}$ & $\begin{array}{l}\text { Chiang and Wang (2011), } \\
\text { Bates et al. (2009), Chang } \\
\text { and Noorbakhsh (2009), } \\
\text { Ozkan and Ozkan (2004), } \\
\text { Opler et al. (1999) }\end{array}$ \\
\hline $\begin{array}{l}\text { Dividend dummy } \\
\text { (div) }\end{array}$ & Negative & & $\begin{array}{l}\text { Dummy variable }=1 \text { if } \\
\text { dividend paid and } 0 \text { if not } \\
\text { paid }\end{array}$ & $\begin{array}{l}\text { Chiang and Wang (2011), } \\
\text { Bates et al. (2009), Foley } \\
\text { et al. (2007), Ozkan and } \\
\text { Ozkan (2004), Opler et al. } \\
\text { (1999) }\end{array}$ \\
\hline $\begin{array}{l}\text { Net working } \\
\text { capital to assets } \\
\text { (nwcap) }\end{array}$ & Negative & & $\begin{array}{l}\text { Current net assets, minus } \\
\text { cash and short-term } \\
\text { investments, divided by } \\
\text { total assets }\end{array}$ & $\begin{array}{l}\text { Chiang and Wang (2011), } \\
\text { Bates et al. (2009), Ozkan } \\
\text { and Ozkan (2004). }\end{array}$ \\
\hline Cash flow (cf) & Negative & Positive & $\begin{array}{l}\text { Cash flow divided by total } \\
\text { assets }\end{array}$ & $\begin{array}{l}\text { M. A. Ferreira and Vilela } \\
\text { (2004), Bates et al. } \\
\text { (2009), Opler } \text { et al. (1999) }\end{array}$ \\
\hline $\begin{array}{l}\text { Variability of cash } \\
\text { flow (cfsd) }\end{array}$ & Positive & & $\begin{array}{l}\text { The standard deviation of } \\
\text { cash flow with } 10 \text { years of } \\
\text { previous observations }\end{array}$ & $\begin{array}{l}\text { Bates et al. (2009), Opler } \\
\text { et al. (1999) }\end{array}$ \\
\hline $\begin{array}{l}\text { Capital } \\
\text { expenditures (cpxa) }\end{array}$ & Negative & Positive & $\begin{array}{l}\text { Ratio between capex and } \\
\text { total assets }\end{array}$ & $\begin{array}{l}\text { Bates et al. (2009), Foley } \\
\text { et al. (2007) }\end{array}$ \\
\hline
\end{tabular}

Note. Source: Authors. 


\section{Data}

Brazil and Mexico were selected because they are the most important economies in Latin America. According to UN statistics, in 2010 these two countries accounted together for $63.2 \%$ of Latin America's GDP and $74.1 \%$ of the market value of publicly traded companies listed in the region. According to the América Economia magazine's 2010 ranking, $63.6 \%$ of the most internationalized companies are Brazilian or Mexican, and $341(68.2 \%)$ of the 500 largest companies in the region are Brazilian or Mexican.

In 2010, Brazilian exports and imports totaled US\$ 383.6 billion, whereas Mexican exports and imports totaled US\$ 600.0 billion. Nevertheless, the Brazilian economy presents a greater spread of international partners, while the Mexican economy depends on the U.S. According to Canuto and Santos (2003), Moody's explains that this strong economic integration with the United States makes the Mexican economy less vulnerable to financial crises. They also affirm that large Mexican companies turn to North American capital markets for financing, reducing the importance of domestic credit for the private sector. In addition, unlike Brazilian firms, Mexican firms use more cash reserves than trade credit during financial crises (Sheng et al., 2013). These differences may lead to different cash behaviors between companies in the two countries.

For Brazil, we considered all Brazilian companies listed on BOVESPA - the São Paulo Stock Exchange. For Mexico, we considered all Mexican companies listed on the Mexican Stock Exchange between 2006 and 2010. The period selected included the crisis of 2008, as well as the two years that preceded and followed it. Following Bates et al. (2009), only companies with positive assets and positive sales throughout the whole sample were considered. Also following Bates et al. (2009), financial companies were excluded because these companies may hold cash to meet capital requirements rather than for the economic reasons studied here. Public utility companies were also excluded because they are subject to high levels of regulation.

The sample includes all Brazilian companies listed on the São Paulo Stock Exchange and all Mexican companies listed on the Mexican Stock Exchange from 2006 to 2010 with positive values for sales and assets. Financial companies and public utilities were excluded from the sample. Companies with unavailable information or financial problems during the whole sample period were also excluded, resulting in a panel with 615 observations for 123 single companies, from which 71 were Brazilian and 52 were Mexican.

Table 2 reports descriptive statistics for Cashr, Doi, Doi2, Size, Lev, Gop, Div, Nwcap, Cf, Cfsd and Cpxa. Note that Div is a dummy variable: 1 for companies paying dividends and 0 for those not paying. In the total 615 observations, 417 companies paid dividends (68\%) and 198 did not (32\%).

Table 2

Descriptive Statistics

\begin{tabular}{lccccc}
\hline Variable & $\mathbf{N}^{\mathbf{0}}$ Observations & Average & $\begin{array}{c}\text { Standard } \\
\text { Deviation }\end{array}$ & Minimum & Maximum \\
\hline Cashr & 615 & 0.110 & 0.099 & 0.000 & 0.531 \\
Doi & 615 & 0.172 & 0.216 & 0.000 & 0.984 \\
doi2 & 615 & 0.076 & 0.149 & 0.000 & 0.968 \\
Size & 615 & 13.788 & 1.773 & 9.148 & 19.559 \\
Lev & 615 & 0.250 & 0.226 & 0.000 & 2.658 \\
Gop & 605 & 1.506 & 0.794 & 0.386 & 6.707 \\
\hline
\end{tabular}

Continues 
Table 2 (continued)

\begin{tabular}{lccccc}
\hline Variable & $\mathbf{N}^{\mathbf{0}}$ Observations & Average & $\begin{array}{c}\text { Standard } \\
\text { Deviation }\end{array}$ & Minimum & Maximum \\
\hline div* & 615 & - & - & - & - \\
Nwcap & 615 & 0.357 & 0.198 & 0.000 & 0.973 \\
Cf & 615 & 0.036 & 0.101 & -0.888 & 0.860 \\
Cfsd & 614 & 0.055 & 0.036 & 0.009 & 0.241 \\
Cpxa & 615 & 0.052 & 0.060 & -0.369 & 0.385 \\
\hline
\end{tabular}

Note. Source: The authors.

Information on the companies was collected from Economática and Thomson Reuters databases, research in EXAME and América Economia magazines, as well as financial reports and company websites. Because Brazilian companies are not required to report their percentage of export revenues, it was not possible to obtain data for some companies. These were therefore discarded from the sample. The difficulty to obtain this variable extended to other Latin American countries and was the leading factor for their exclusion from our study.

Companies that experienced financial problems over the entire sample period were also disregarded. The final sample contained 123 selected companies - 71 companies in Brazil and 52 in Mexico, with a total of 604 observations in total.

\section{Methodology}

To investigate whether the degree of internationalization is a determinant of cash, we performed a multiple regression with a fixed effects panel. We applied the Hausman test (1978), and its p-value of was less than 0.001 . Therefore we rejected the Ho and the fixed effects model was chosen.

To test for the existence of heteroscedasticity problems, we followed the Breusch-Pagan test (1980). We identified problems with heteroscedasticity (p-value of the test was less than 0.001), and robust standard errors for heteroscedasticity were used as a corrective measure.

The Variance Inflation Factor (VIF) was also calculated and as it had no major effect above 10, no multicollinearity problems were detected.

For the comparison between the Brazilian and Mexican companies, we created interactions between a country dummy (where Brazil $=1$ and Mexico $=0$ ) and all other variables. Due to the use of panel regression with fixed effects, the country dummy was not included in the model and the comparison between companies in Brazil and Mexico was indirectly included through interactions between the country dummy and the variables.

If the interaction between the country dummy and the variable is not significant, the effect of that variable upon cash levels is the same for Mexican and Brazilian companies, that is, there is no difference in its influence on cash levels for both countries. If the interaction is significant, the influence of this variable on cash levels affects Mexican and Brazilian companies differently.

In addition to the determinants of cash already found in the literature, following Chiang and Wang (2011), we introduced the degree of internationalization (DOI) and the squared degree of internationalization (DOI2). If DOI and/or DOI2 are significant, the degree of internationalization of the company is a determinant of cash and this variable influences company cash levels and should be considered in further studies/ research. The following equation was the used for the regression: 
$\boldsymbol{C a s h r}_{i t}=\beta 0_{i t}+\boldsymbol{\beta 1 d o i _ { i t } + \boldsymbol { \beta } 2 \text { doi } _ { i t } + \beta 3 \text { size } _ { i t } + \beta 4 \text { lev } _ { i t } + \beta 5 g o p c _ { i t } + \beta 6 \operatorname { d i v } _ { i t } + \beta 7 n w c a p _ { i t } +} \beta 8 c f_{i t+}$

$$
\begin{aligned}
& \begin{array}{lllllllll}
(0.647) & (-0.110) & (0.318) & (-0.026) & (0.072) & (0.031) & (0.004) & (-0.367) & (0,188)
\end{array} \\
& { }_{+} \beta 9 c f s d_{i t+} \beta 10 c p x a_{i t}+\beta 11 d_{-} d o i_{i t}+\beta 12 d \_d o i 2_{i t+} \beta 13 d \_s i z e_{i t}+\beta 14 d \_l e v_{i t+} \beta 15 d \_g o p_{i t+} \\
& \begin{array}{lllllll}
(-0.260) & (-0.251) & (-0.055) & (-0.029) & (-0.007) & (-0.039) & (-0.013)
\end{array} \\
& +\beta 16 d \_d i v_{i t}+\beta 17 d \_n w c a p p_{i t}+\beta 18 d \_c f i t+\beta 19 d \_c f s d_{i t}+\beta 20 d \_c p x a+\varepsilon_{i t} \\
& \begin{array}{lllll}
(0.032) & (-0.194) & (-0.153) & (0.157) & (0.098)
\end{array}
\end{aligned}
$$

Where:

. Cashr $=$ Cash ratio

. doi = degree of internationalization (new variable in the model),

- doi2 = squared gdi (new variable in the model),

. size = company size,

- lev = company leverage,

. gop = growth opportunity,

- $\operatorname{div}=$ dividend dummy ( 1 for companies paying dividends and 0 for not paying)

- nwcap $=$ net working capital to assets,

. $\mathrm{cf}=$ cash flow over total assets $(\mathrm{fcx})$

- $\quad \operatorname{cfsd}=$ variability of cash flow

- $\quad$ pxa $=$ capital expenditures (capex),

. d_doi = interaction between country dummy and doi,

- d_doi $2=$ interaction between country dummy and doi2,

. d_size $=$ interaction between country dummy and size,

. d_lev = interaction between country dummy and lev,

. d_ gop = interaction between country dummy and gop,

. d_div = interaction between country dummy and div,

. d_nwcap $=$ interaction between country dummy and nwcap,

. d_cf = interaction between country dummy and cf,

. d_cfsd = interaction between country dummy and cfsd,

. d_cpxa = interaction between country dummy and cpxa

. $\mathrm{e}=$ error

. $\mathrm{i}=$ companies analyzed

. $\mathrm{t}=$ period of time under analysis 


\section{Results}

We applied the same regression used by Bates et al. (2009) to Brazil and Mexico. The Trade-Off theory prediction was confirmed. The variables for company size, net working capital to assets and capital expenditures showed negative and significant coefficients. The coefficient of the growth opportunity variable was positive and significant. These results were the same as those found by Bates et al. (2009). However, the variability of cash flow and leverage variables were significant in the regression of Bates et al. (2009) for U.S. companies, but were not significant for Brazil and Mexico. The cash flow over assets variable was not significant both for U.S. companies and for Brazilian and Mexican companies. The dividend dummy variable was positive and significant, in opposition to the sign found by Bates et al. (2009). The results are demonstrated in Table A1 of the Appendix.

In order to analyze the possible influence by the period chosen in our database, we included a time dummy (t1) for the pre-crisis period (in which 2006 and 2007 are 1 and other years are 0) and another time dummy (t2) for the post-crisis period (2009 and $2010=1$ and the other years $=0$ ). In line with expectations, the period before the crisis was negative and significant, given that before the crisis companies had more access to credit lines and capital markets and therefore did not need to hold cash for precautionary reasons, as discussed in the literature in section 2 . The variables for size, growth opportunity, net working capital to assets and capital expenditures remained significant and showed the same sign as in the previous test, in accordance with the Trade-Off theory. The dummy dividend became insignificant (Table A2 of the Appendix).

For the analysis of the proposed subject with the inclusion of our test variables DOI and DOI2, and the interactions between the country dummy and all variables, the coefficients of the variables in the new regression remained negative and significant for company size, net working capital to assets and capital expenditures (see Table 3). The coefficient of the growth opportunity variable remained positive and significant, in line with the Trade-Off and Pecking Order theories. The variables for leverage and variability of cash flow remained insignificant. In the new regression, cash flow over assets showed a positive and significant coefficient.

Table 3

Regression Results: Internationalization and Cash Level

\begin{tabular}{ccc} 
& Coefficients & P-Value \\
\hline Doi & -0.110 & 0.440 \\
doi2 & $0.318^{* *}$ & 0.041 \\
Size & $-0.026^{*}$ & 0.063 \\
Lev & 0.072 & 0.130 \\
Gop & $0.031^{* * *}$ & 0.001 \\
Div & 0.004 & 0.522 \\
nwcap & $-0.367^{*}$ & 0.001 \\
Cf & $0.188^{* *}$ & 0.038 \\
Cfsd & -0.260 & 0.151 \\
Cpxa & $-0.251^{*}$ & 0.001 \\
d_doi & -0.055 & 0.803 \\
d_doi2 & -0.029 & 0.908 \\
\hline
\end{tabular}


Table 3 (continued)

\begin{tabular}{ccc}
\cline { 2 - 3 } & Coefficients & P-Value \\
\hline d_size & -0.007 & 0.508 \\
d_lev & -0.039 & 0.467 \\
d_gop & -0.013 & 0.197 \\
d_div & $0.032^{* *}$ & 0.048 \\
d_nwcap & -0.194 & 0.125 \\
d_cf & -0.153 & 0.118 \\
d_cfsd & 0.157 & 0.533 \\
d_cpxa & 0.098 & 0.279 \\
constant & $0.647^{* * *}$ & 0.001 \\
\hline R-Squared & & $\mathbf{0 . 3 7 2}$ \\
\hline Number of observations & & $\mathbf{6 0 4}$ \\
\hline
\end{tabular}

Note. This table shows the results of the panel regression with fixed effects in our study. The dependent variable is level of cash (Nivcx) and the test variable is the degree of internationalization (GDI). The Hausman test (1987) was performed for selection of the consistent model (p-test value <0.001). We applied the Breuch-Pagan test (1980) and used robust standard errors for heteroscedasticity correction ( $\mathrm{p}$-value test $<0.001)$. There were no multicollinearity problems. Source: The authors.

$* 10 \%$ Significant, $* * 5 \%$ Significant and $* * * 1 \%$ Significant

In the analysis between the countries, the interaction between the country dummy and the dividend variable was the only difference detected. The cash ratio of dividend-paying Brazilian companies is positively affected, but there was no evidence of influence on the cash of Mexican companies, as the main effect of the dividends was not significant. This result differed from the one presented by Bates et al. (2009), other previous studies, and from the Trade-Off theory.

The conflict between controlling and minority shareholders (Lopes \& Walker, 2008) could be a possible explanation, in contrast with other markets, where there is conflict between shareholders and managers (Jensen, 1986). In Brazil, profit-generating companies are required to distribute dividends. However, the distinction between common shares (voting) and preferred shares (non-voting) may lead voting shareholders (without preference in the receipt of dividends) to a lack of interest in paying the dividend, therefore adhering to conservative accounting practices (Ahmed, Billings, Morton, \& Stanford-Harris, 2002). Along with the change in company statutes (under article 202 of Law 6404/76, company statutes are sovereign in setting the percentage of profit to be distributed), they may pay the minimum dividend and keep the rest in cash. Thus, a company that generates large profits can distribute the minimum amount possible and keep what is left in cash.

The squared degree of internationalization (DOI2) test variable was positive and significant, providing evidence that this variable is a determinant of cash and that the level of cash increases quadratically as the degree of internationalization of a company increases.

One possible explanation is the access to financing in foreign currency for exporters/importers from Brazil and Mexico, where interest rates are lower. They may invest these resources in fixed income in their respective countries, thereby gaining with the differential interest rate, and taking advantage of interest rate arbitrage between countries.

The results for our test variables DOI and DOI2 were different from those found by Chiang and Wang (2011), which were based on the United States. We can therefore affirm that the theory/modeling tested by Chiang and Wang (2011) did not apply for Brazilian and Mexican companies. Their behavior of cash holding and internationalization was shown to be different. Thus, further research would be required to justify this difference and add new variables that might influence this behavior and have not been tested for in this study. 
We also included a time dummy (t1) for the period before the crisis (in which 2006 and 2007 are 1 and other years are 0 ) and a time dummy (t2) for the period after the crisis (2009 and $2010=1$ and the other years $=0$ ) to test the effect of 2008 crisis on cash in Table 4 .

Table 4

Regression Results: Internationalization, Level of Cash and Time Dummy

\begin{tabular}{|c|c|c|c|c|c|c|}
\hline & \multicolumn{2}{|c|}{$\begin{array}{l}\text { Brazil and Mexico (all } \\
\text { samples) }\end{array}$} & \multicolumn{2}{|c|}{$\begin{array}{l}\text { Mexico (Model without } \\
\text { div dummy) }\end{array}$} & \multicolumn{2}{|c|}{$\begin{array}{l}\text { Brazil (Model without } \\
\text { div dummy) }\end{array}$} \\
\hline & Coefficients & P-Value & Coefficients & P-Value & Coefficients & P-Value \\
\hline $\mathrm{t} 1$ & $-0.012^{*}$ & 0.074 & -0.008 & 0.277 & $-0.021 * *$ & 0.045 \\
\hline $\mathrm{t} 2$ & -0.008 & 0.253 & -0.005 & 0.443 & -0.015 & 0.283 \\
\hline Doi & -0.129 & 0.339 & -0.239 & 0.122 & -0.220 & 0.214 \\
\hline doi2 & $0.335^{* *}$ & 0.026 & $0.404 * *$ & 0.025 & $0.471^{* *}$ & 0.031 \\
\hline Size & -0.024 & 0.141 & 0.020 & 0.312 & $-0.041 * *$ & 0.023 \\
\hline Lev & 0.052 & 0.273 & 0.031 & 0.493 & 0.000 & 0.989 \\
\hline Gop & $0.036 * * *$ & 0.001 & $0.032 * * *$ & $<0.000$ & $0.026 * * *$ & 0.003 \\
\hline Div & 0.001 & 0.802 & - & - & - & - \\
\hline Nwcap & $-0.379 * * *$ & 0.001 & $-0.363 * * *$ & $<0.000$ & $-0.566^{* * *}$ & $<0.000$ \\
\hline $\mathrm{Cf}$ & $0.181 * *$ & 0.034 & $0.160^{*}$ & 0.054 & 0.054 & 0.184 \\
\hline Cfsd & -0.281 & 0.138 & -0.238 & 0.172 & -0.121 & 0.515 \\
\hline Сpxa & $-0.265^{* * *}$ & 0.001 & $-0.277 * * *$ & $<0.000$ & $-0.188 * *$ & 0.020 \\
\hline d_doi & 0.003 & 0.988 & - & - & - & - \\
\hline d_doi2 & -0.090 & 0.713 & - & - & - & - \\
\hline d_size & -0.008 & 0.459 & - & - & - & - \\
\hline d_lev & -0.029 & 0.588 & - & - & - & - \\
\hline d_gop & -0.014 & 0.161 & - & - & - & - \\
\hline d_div & $0.033 * *$ & 0.043 & - & - & - & - \\
\hline d_nwcap & -0.186 & 0.145 & - & - & - & - \\
\hline d_cf & -0.141 & 0.124 & - & - & - & - \\
\hline d_cfsd & 0.163 & 0.523 & - & - & - & - \\
\hline d_cpxa & 0.102 & 0.274 & - & - & - & - \\
\hline Constant ${ }^{* * *}$ & $0.634 * * *$ & 0.001 & -0.096 & 0.720 & $0.906^{* * *}$ & 0.001 \\
\hline R-Squared & & 0.377 & & 0.393 & & 0.373 \\
\hline Number of observations & & 604 & & 251 & & 353 \\
\hline
\end{tabular}

Note. This table shows the results of the panel regression with fixed effects in our study. We first tested our hypothesis on all samples (Brazil and Mexico), then we tested it separately for each country. The dependent variable is level of cash (Nivcx) and the test variable is level of internationalization (GDI), with the inclusion of time dummies t1 (1 for 2006 and 2007 and 0 for others) and t2 (1 for 2009 and 2010). The Hausman test (1987) was performed for selection of the consistent model (p-test value $<0.001)$. We applied the Breuch-Pagan test (1980) and used robust standard errors for heteroscedasticity correction ( $\mathrm{p}$ value test $<0.001)$. No multicollinearity problems were identified. Source: The authors.

$* 10 \%$ Significant, $* * 5 \%$ Significant and $* * * 1 \%$ Significant 
First, we test our hypotheses on all samples (Brazilian firms plus Mexican firms), as that would increase the sample size and increase the power of the tests performed for the coefficients. Even though the comparison between the two countries is not the main variable (as both of them have characteristics that may influence the answer variable), we included a dummy identifying the two countries as a control variable.

As two countries may present different baseline values as well as coefficients that differ from the control and interest variables employed in the model, we included interactions between these variables and the country dummy. The presence of such interactions enables the use of a single model, while also allowing the two countries to have different influences from the independent variables in the dependent one.

The period before the crisis was negative and significant. Our test variable, DOI2, remained positive and significant. The variables for growth opportunity, net working capital to assets, cash flow, capital expenditures and interaction between the country dummy and dividends remained significant and followed the same sign as the previous test, which is in line with the literature. The size variable became insignificant.

In addition, we also studied each country separately to verify the effect of potential differences of dividend regulation in each country (Column 2 and 3 in Table 4). We find supportive evidence to all sample results both in Mexican firms and in Brazilian firms. Not only the internationalization variable DOI2 but also the main control variables remain significant.

\section{Conclusion}

Multinational companies start their international expansion through exports (Johanson \& Vahlne, 1977). In our study, we found evidence that the degree of internationalization, defined as percentage of export sales, is a determinant of cash for companies in Brazil and Mexico, in line with Chiang and Wang (2011). The greater the degree of internationalization, the more cash the company holds, controlled by variables suggested by the literature such as company size, leverage, growth opportunity, dividends, net assets, cash flow, variability of cash flow and capital investment.

Unlike Chiang and Wang's study, the relationship between the degree of internationalization and cash ratio shows a different behavior for companies in Brazil and Mexico. There is evidence that this behavior increases quadratically. This behavior remain significant even when we tested our hypotheses on separate country samples. We believe that the increase is caused by access to financing with special foreign currency lines available to Brazilian and Mexican exporting/importing companies. They invest these resources in fixed income funds in their respective countries and gain through the interest rate differential.

The period before the crisis was significant and had a negative sign, showing that companies held less cash on their balance sheets, in line with a period in which access to credit lines and capital markets were more abundant for companies. Despite Mexican and Brazilian companies facing different financing constraints, the only difference detected was related to the dividend dummy, which positively affected the level of cash in Brazilian companies but showed no signs of affecting cash in Mexican companies. A possible explanation could be the conflict between controlling and minority shareholders and a loophole in the Limited Companies Law in Brazil, as discussed in section Results above.

The complementarity between the Trade-Off and Pecking Order theories was also relevant as control variables in the corporate cash study. These results are in line with Koshio (2005), who also found this complementarity of theories while studying cash levels and corporate value: when a company's cash level is sensitive to company value, their decisions are based on the Trade-Off theory; however, they let their cash level follow the Pecking Order when the relationship between cash level and the variable is not sensitive. 
Finally, these results have important implications for future studies. Companies with a higher degree of internationalization show different cash-level behaviors than domestic companies, and companies in Brazil and Mexico show different behaviors than U.S. companies with respect to increased internationalization. Thus, companies planning to internationalize or scholars who wish to expand on the subject should take the degree of internationalization into account.

The small size of our sample and the exclusion of companies with no export percentage from our database represent the main limitations of study. Therefore, for future studies, more countries/companies could be included in our sample for comparison and a more detailed analysis of the subject. In addition, the effect of government regulation on firm dividend policies may require detailed investigation. For a further development of the topic, other theories could be studied to explain corporate cash behavior, such as the one by M. A. Ferreira and Vilela (2004), which argues that cash holding allows the pursuance of investment projects with positive net present value (NPV) even when financial constraints are met.

\section{References}

Acharya, V. V., Almeida, H., \& Campello, M. (2007). Is cash negative debt? A hedging perspective on corporate financial policies. Journal of Financial Intermediation, 16(4), 515-554. doi: 10.1016/j.jfi.2007.04.001

Ahmed, A. S., Billings, B. K., Morton, R. M., \& Stanford-Harris, M. (2002). The role of accounting conservatism in mitigating bondholder-shareholder conflicts over dividend policy and in reducing debt costs. The Accounting Review, 77(4), 867-890. doi: 10.2308/accr.2002.77.4.867

Almeida, H., \& Campello, M. (2007). Financial constraints, asset tangibility and corporate investment. The Review of Financial Studies, 20(5), 1429-1460. doi: 10.3386/w12087

Almeida, H., Canpello, M., \& Weisbach, M. (2002). Corporate demand for liquidity [Working Paper $\mathrm{n}^{\circ}$ 9253]. National Bureau of Economic Research, Cambridge, MA.

Bates, T. W., Kahle, K. M., \& Stulz, R. M. (2009). Why do U.S. firms hold so much more cash than they used to?. The Journal of Finance, 64(5), 1985-2021. doi: 10.1111/j.1540-6261.2009.01492.x

Baumol, W. (1952). The transaction demand for cash: an inventory theoretic approach. The Quarterly Journal of Economics, 66(4), 545-556. doi: 10.2307/1882104

Benegas, R. M. P. (2008). A importância do caixa para as empresas brasileiras: uma análise comparativa entre períodos de pré-crise (1995-1997), crise (1998-2003) e pós-crise (2004-2006) (Dissertação de mestrado). Faculdade IBMEC de São Paulo, SP, Brasil.

Canuto, O., \& Santos, P. F. P. dos (2003). Risco soberano e prêmios de risco em economias emergentes (Temas de Economia Internacional 01). Brasília: Ministério da Fazenda, Secretaria de Assuntos Internacionais.

Recuperado

de http://www.ie.ufrj.br/hpp/intranet/pdfs/canuto_o._e_santos_p._risco_soberano_e_premios_de_ri sco_2003.pdf

Carracedo, A. (2010). Determinantes da reserva de caixa das empresas brasileiras (Dissertação de mestrado). Universidade de São Paulo, Escola de Administração de Empresas de São Paulo, São Paulo, SP, Brasil.

Chang, K., \& Noorbakhsh, A. (2006). Corporate cash holdings, foreign direct investment, and corporate governance. Global Finance Journal, 16(3), 302-316. doi: 10.1016/j.gfj.2006.01.004 
Chang, K., \& Noorbakhsh, A. (2009). Does national culture affect international corporate cash holdings?. Journal of Multinational Financial Management, 19(5), 323-342. doi: 10.1016/j.mulfin.2009.07.001

Chiang, Y.-C., \& Wang, C.-D. (2011). Corporate international activities and cash holdings. African Journal of Business Management, 5(7), 2992-3000. doi: 10.5897/AJBM10.1517

Desai, M. A., Foley, C. F., \& Hines, J. R., Jr. (2004). A multinational perspective on capital structure choice and internal capital markets. The Journal of Finance, 59(6), 2451-2487. doi: $10.1111 /$ j.1540-6261.2004.00706.x

Dittmar, A., \& Mahrt-Smith, J. (2007). Corporate governance and the value of cash holdings. Journal of Financial Economics, 83(3), 599-634. doi: 10.1016/j.jfineco.2005.12.006

Dittmar, A., Mahrt-Smith, J., \& Servaes, H. (2003). International corporate governance and corporate cash holdings. Journal of Financial and Quantitative Analysis, 38(1), 111-133.

Doukas, J. A., \& Pantzalis, C. (2003). Geographic diversification and agency costs of debt of multinational firms. Journal of Corporate Finance, 9(1), 59-92.

Dylewski, C. (2010). Determinantes do nível de caixa das empresas: análise de amostra de países da América Latina (Dissertação de mestrado). Fundação Getúlio Vargas, Escola de Economia de São Paulo, São Paulo, SP, Brasil.

Faleye, O. (2004). Cash and corporate control. The Journal of Finance, 59(5), 2041-2060.

Ferreira, E. J., \& Leal, R. P. C. (2010). Examining cash holdings of U.S. and Brazilian firms. Journal of International Business and Economics, 10(3), 75-84.

Ferreira, M. A., \& Vilela, A. S. (2004). Why do firms hold cash? Evidence from EMU countries. European Financial Management, 10(2), 295-319. doi: 10.1111/j.1354-7798.2004.00251.x

Foley, C. F., Hartzell, J. C., Titman, S., \& Twite, G. (2007). Why do firms hold so much cash? A taxbased explanation. Journal of Financial Economics, 86(3), 579-607. doi: 10.3386/w12649

Freitas, B. (2006). A geração interna de recursos como fator determinante do investimento em capital fixo realizado por empresas brasileiras de capital aberto (Dissertação de mestrado). Universidade de São Paulo, Faculdade de Economia, Administração e Contabilidade, São Paulo, SP, Brasil.

Harford, J., Mansi, S. A., \& Maxwell, W. F. (2008). Corporate governance and a firm cash holdings in the US. Journal of Financial Economics, 87(3), 535-555. doi: 10.1016/j.jfineco.2007.04.002

Jensen, M. (1986). Agency costs of free cash flow, corporate finance and takeovers. American Economic Review, 76(2), 323-329.

Johanson J., \& Vahlne, J.-E. (1977). The internationalization process of the firm-a model of knowledge development and increasing foreign market commitments. Journal of International Business Studies, 8(1), 23-32. doi: 10.1057/palgrave.jibs.8490676

Keynes, J. M. (2009). The general theory of employment, interest and money. New York, USA: Classic Books America. (Obra original publicada em 1936)

Kirch, G., Procianoy, J. L., \& Terra, P. R. S. (2014). Restrições financeiras e decisão de investimento das firmas brasileiras. Revista Brasileira de Economia, 68(1), 103-123. doi: 10.1590/S003471402014000100006 
Koshio, S. (2005). Nível de caixa de empresas não financeiras no Brasil: determinantes e relação com $o$ endividamento (Tese de doutorado). Fundação Getulio Vargas, Escola de Administração de Empresas de São Paulo, São Paulo, SP, Brasil.

Lopes, A., \& Walker, M. (2008). Firm-level incentives and the informativenessos accounting reports: an experiment in Brazil [Working Paper]. Universidade de São Paulo e Manchester Business School, São Paulo, SP, Brasil and Manchester, UK.

Lu, J. W., \& Beamish P. W. (2004). International diversification and firm performance: the s-curve hypothesis. The Academy of Management Journal, 47(4), 598-609. doi: 10.2307/20159604

Miller, M. H., \& Orr, D. (1966). A model of the demand for money by firms. The Quarterly Journal of Economics, 80(3), 413-435. doi: 10.2307/1880728

Mulligan, C. (1997). Scale economies, the value of time, and the demand for money: longitudinal evidence from firms. Journal of Political Economy, 105(5), 1061-1079. doi: 10.1086/262105

Myers, S. C. (1984). The capital structure puzzle. Journal of Finance, 39(3), 574-592. doi: 10.1111/j.1540-6261.1984.tb03646.x

Opler, T., Pinkowitz, L., Stulz, R., \& Williamson, R. (1999). The determinants and implications of corporate cash holdings. Journal of Financial Economics, 52(1), 3-46. doi: 10.1016/S0304405X(99)00003-3

Ozkan, A., \& Ozkan, N. (2004). Corporate cash holdings: an empirical investigation of UK companies. Journal of Banking \& Finance, 28(9), 2103-2134. doi: 10.1016/j.jbankfin.2003.08.003

Pereira, E. (2011). Restrição financeira e financiamento para empresas latino-americanas: evidência do Brasil e México (Dissertação de mestrado). Fundação Getulio Vargas, Escola de Economia de São Paulo, São Paulo, SP, Brasil.

Reeb, D. M., Kwok, C. C. Y., \& Baek, H. Y. (1998). Systematic risk of the multinational corporation. Journal of International Business Studies, 29(2), 263-279. doi: 10.1057/palgrave.jibs. 8490036

Sheng, H. H., Bortoluzzo, A. B., \& Santos, G. A. P. dos (2013). Impact of trade credit on firm inventory investment during financial crises: evidence from Latin America. Emerging Market Finance \& Trade, 49(Suppl. 4), 35-55. doi: 10.2753/REE1540-496X4905S403

Sullivan, D. (1994). Measuring the degree of internationalization of a firm. Journal of International Business Studies, 25(2), 325-342. doi: 10.1057/palgrave.jibs.8490203

Titman, S., \& Wessels, R. (1988). The determinants of capital structure choice. The Journal of Finance, 43(1), 1-19. doi: 10.1111/j.1540-6261.1988.tb02585.x

Zani, J., \& Procianoy, J. L. (2005, julho). Restrição financeira e a política financeira da firma: a variação na estocagem de liquidez determinada pelo status financeiro e pela sua geração de caixa operacion. Anais do Encontro Brasileiro de Finanças, São Paulo, SP, Brasil, 5.

\section{Dados dos Autores}

Newton Arata

Rua Itapeva, 474, 01332-000, São Paulo, SP, Brasil. E-mail: nw_arata@ hotmail.com

Hsia Hua Sheng

Rua Itapeva, 474, 01332-000, São Paulo, SP, Brasil. E-mail: hsia.sheng@ fgv.br

Mayra Ivanoff Lora

Rua Itapeva, 474, 01332-000, São Paulo, SP, Brasil. E-mail: Mayra.Lora@fgv.br

RAC, Rio de Janeiro, v. 19, Edição Especial, art. 1, pp. 1-19, Maio 2015

WwW.anpad.org.br/rac (oc) EY- 


\section{APPENDIX}

Table A1

Regression Results: Determinants of Level of Cash

\begin{tabular}{lll}
\cline { 2 - 3 } & Coefficients & P-Value \\
\hline size & $-0.029 * * *$ & 0.004 \\
Lev & 0.024 & 0.304 \\
gop & $0.022^{* * *}$ & 0.001 \\
div & $0.014^{*}$ & 0.067 \\
nwcap & $-0.516^{* * *}$ & 0.001 \\
Cf & 0.061 & 0.152 \\
Cfsd & -0.181 & 0.197 \\
cpxa & $-0.168^{* * *}$ & 0.001 \\
\hline Constant & $0.668^{* * *}$ & 0.001 \\
\hline R-Squared & & $\mathbf{0 . 3 4 2}$ \\
Number of observations & & $\mathbf{6 0 4}$ \\
\hline
\end{tabular}

Note. This table shows the results of the panel regression with fixed effects in our study. The dependent variable is level of cash (Nivcx). The Hausman test (1987) was performed for selection of the consistent model (p-test value <0.001). We applied the Breuch-Pagan test (1980) and used robust standard errors for heteroscedasticity correction (p-value test <0.001). No multicollinearity problems were identified. Source: Authors.

$* 10 \%$ Significant, $* * 5 \%$ Significant and $* * * 1 \%$ Significant.

Table A2

Regression Results: Determinants of the Level of Cash and Time Dummy

\begin{tabular}{lll} 
& Coefficients & P-Value \\
\hline $\mathrm{t} 1$ & $-0.013^{* *}$ & 0.047 \\
$\mathrm{t} 2$ & -0.010 & 0.186 \\
size & $-0.028^{* *}$ & 0.028 \\
Lev & 0.012 & 0.636 \\
gop & $0.027^{* * *}$ & 0.001 \\
Div & 0.012 & 0.121 \\
nwcap & $-0.522^{* * *}$ & 0.001 \\
Cf & 0.065 & 0.107 \\
Cfsd & -0.192 & 0.183 \\
cpxa & $-0.185^{* * *}$ & 0.001 \\
\hline constant & $0.665^{* * *}$ & 0.001 \\
\hline R-Squared & & $\mathbf{0 . 3 4 8}$ \\
Number of observations & & $\mathbf{6 0 4}$ \\
\hline
\end{tabular}

Note. This table shows the results of the panel regression with fixed effects in our study. The dependent variable is level of cash (Nivcx) with the inclusion of time dummies t 1 ( 1 for 2006 and 2007 and 0 for others) and 2 ( 1 for 2009 and 2010). The Hausman test (1987) was performed for selection of the consistent model (p-test value <0.001). We applied the Breuch-Pagan test (1980) and used robust standard errors for heteroscedasticity correction (p-value test $<0.001$ ). No multicollinearity problems were identified. Source: Authors.

* $10 \%$ Significant, $* * 5 \%$ Significant and $* * * 1 \%$ Significant. 